\title{
The Impact of European Enlargement on the Direction and Prospects of Brussels Exports
}

Karolien De Bruyne Jan Van Hove

HUB RESEARCH PAPERS 2012/39 ECONOMICS \& MANAGEMENT NOVEMBER 2012
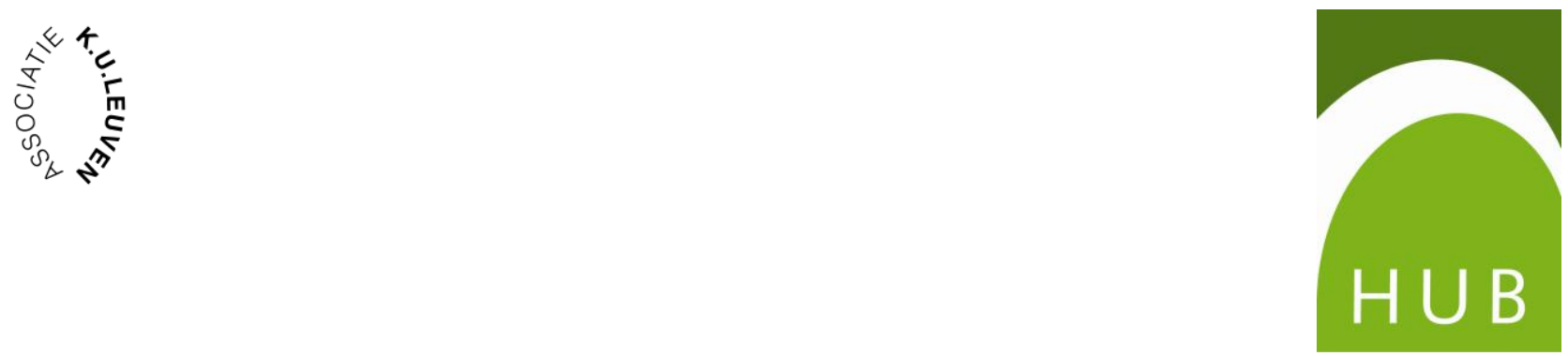


\title{
The Impact of European Enlargement on the Direction and Prospects of Brussels Exports
}

\author{
Karolien De Bruyne \\ H.U.Brussel and University of Leuven \\ and \\ Jan Van Hove \\ H.U.Brussel and University of Leuven
}

November 2012

\begin{abstract}
Previous studies have argued that the enlargement of the European Union triggered a geographical reorientation and diversification in the exports by European Union member states, caused by a combination of trade creation and trade diversion. This paper adds to the existing literature, by analyzing the export dynamics and potentials of a city rather than a country. It focuses on Brussels, the European capital. Our findings indicate that the new European Union member states became important destination markets for Brussels exports in recent years. Moreover, there appear to be large export potentials for Brussels products, in particular in Latin American and certain Asian markets. The export potentials within the European Union are more limited, although several new European Union member states are likely to become more important trading partners.

Keywords: European integration, Brussels, European Union, cities, exports

\section{Acknowledgements}

The authors wish to thank the Brussels government for financial support. They also acknowledge useful comments by Jarko Fidrmuc, Miroslav Jovanovic, Louise Curran, Camelia Turcu, Elias Soukiazis, Pedro Cerqueira as well as by an anonymous referee. Corresponding Authors: Karolien De Bruyne, H.U.Brussel, Warmoesberg 26, B-1000 Brussels, Belgium - and - Jan Van Hove, University of Leuven, Centre for Economic Studies, Naamsestraat 69, B-3000 Leuven, Belgium.
\end{abstract}




\section{Introduction}

Because of globalization, the world is becoming our home. In particular international business is taking advantage of this evolution. Thanks to reduced barriers to international trade, companies can seek international expansion by exporting or investing in foreign countries. Rather than staying close to home, many companies now opt for expansion towards new markets further away from home.

Although barriers to international trade have been substantially reduced over the past decades, the extent of the reduction is unevenly spread geographically. In particular, regional trade integration in many parts of the world reduces barriers to trade more substantially than multilateral trade negotiations in the framework of the World Trade Organization. One of the most successful regional integration initiatives has been the European Union integration process. Although it goes far beyond trade liberalization only, its central purpose has always been to create a large single market in which international business can boom and where new trade opportunities are being developed.

Given the recent geographical expansion of the European Union in 2004 and 2007 to include twelve new member states in Central and Eastern Europe (as well as in the Mediterranean Sea), it is not unlikely that the geographical span of European companies' activities changed too. Apart from the well-known facts, first, that the EU enlargement process leads to a large trade creation effect (May (2009), Shepotylo (2010)), and secondly, that exports and investments from the new member states are directed to a large extent towards the other European Union member states (Baldwin et al (1997), Baldwin (2001), Bussiere et al (2008)), many studies show that also EU15 countries expanded their export and investment activities in Central and Eastern Europe. As such the relative position of the new European markets became more important at the expense, at least in relative terms, of the traditional EU15 markets (see a.o.Hoekman et al (1998), Hoekman et al (1999), Winiecki (2000), Abraham et al (2001), Kandogan (2006)).

In this paper we will focus on the impact of EU enlargement on the direction of exports. Given the overwhelming evidence of a geographical reorientation and diversification of European Union member states exports, we focus instead on the impact on the direction of exports by companies based in one single city, namely in Brussels. Since Brussels is the capital city of the European Union, it is interesting to study whether and to what extent exports by Brussels-based companies are reoriented or become more geographically diversified towards the markets of the new European Union member states. To the best of our knowledge, this is the first attempt to study the impact of EU enlargement on the exports originating from one city ${ }^{1}$. Therefore, the insights from this study may be helpful to judge the usefulness of future studies looking at the impact of EU enlargement on other cities too. Next, apart from studying the impact of EU enlargement on current Brussels exports, we also make predictions about the future trade pattern between Brussels and its export destination markets.

\footnotetext{
${ }^{1}$ Note that we study the whole Brussels Capital Region which consists of 19 municipalities - and not merely the center of Brussels.
} 
Apart from any intra-European export reallocations, increasing globalization may of course also affect Brussels exports in a different way, namely by increasing the importance of far-away nonEuropean markets, in particular in emerging economies. Hence the intra-European export reallocation effect may be affected by new export opportunities in these markets too.

Hence the purpose of this paper is twofold. The first objective is to map the evolution in the recent Brussels exports since 2002. Next, we aim to make predictions regarding the future evolution of these trade flows. In our first part on the recent and current exports of Brussels we focus on both goods and services. In the following section, we use a gravity model to define the main determinants of Brussels exports. We are not the first ones to use this framework in the context of EU enlargement (see e.g., Nahuis (2004), Papazoglou et al (2006), Bussiere et al (2008), Shepotylo et al (2010). The novelty of our paper, however, is the focus on a city area within a country rather than on the country itself. Estimation of this model for different sectors allows us to differentiate between the sectors considered. Using these gravity estimation results, we are able to make predictions regarding the future Brussels exports in Section 5. This allows us to compare, for each destination market, the current exports and the potential exports. As such we are able to predict whether Brussels exports to that market are likely to expand or shrink in the future. Hence this analysis allows us to determine which export markets offer the best opportunities for Brussels companies. 


\section{Overview of Brussels exports}

Before making predictions regarding the future of Brussels' trading position, we need to fully understand the current situation. We therefore provide an overview of Brussels exports starting in 2002 until 2007, leaving out the impact of the financial and economic crisis since 2008. We focus on the main trading partners of Brussels, distinguishing between the industry and the services sector.

\subsection{General overview}

It is generally known that exports of both goods and services has been increasing worldwide with a small, but increasing share of trade in services. Brussels is, however, in a special position. Figure 1 plots the exports of the Brussels capital region from 2002 until 2007 for both the goods and the services sector. It immediately becomes clear that the services exports have experienced a steep increase while the goods exports - that only constituted less than $1 / 5^{\text {th }}$ of the services exports in 2002 - have declined further. It is therefore obvious that we need to make a clear distinction between the two sectors when we focus on the Brussels trading position. These evolutions for Brussels reflect the general deindustrialization of the Belgian economy, similar to most western countries. As a capital region and as headquarter of many services firms, however, Brussels is much more focused on (national and international) services provision than the remainder of Belgium.

Figure 1: Evolution of goods and services exports in Brussels Capital Region from 2002-2007 (in mio Euro)

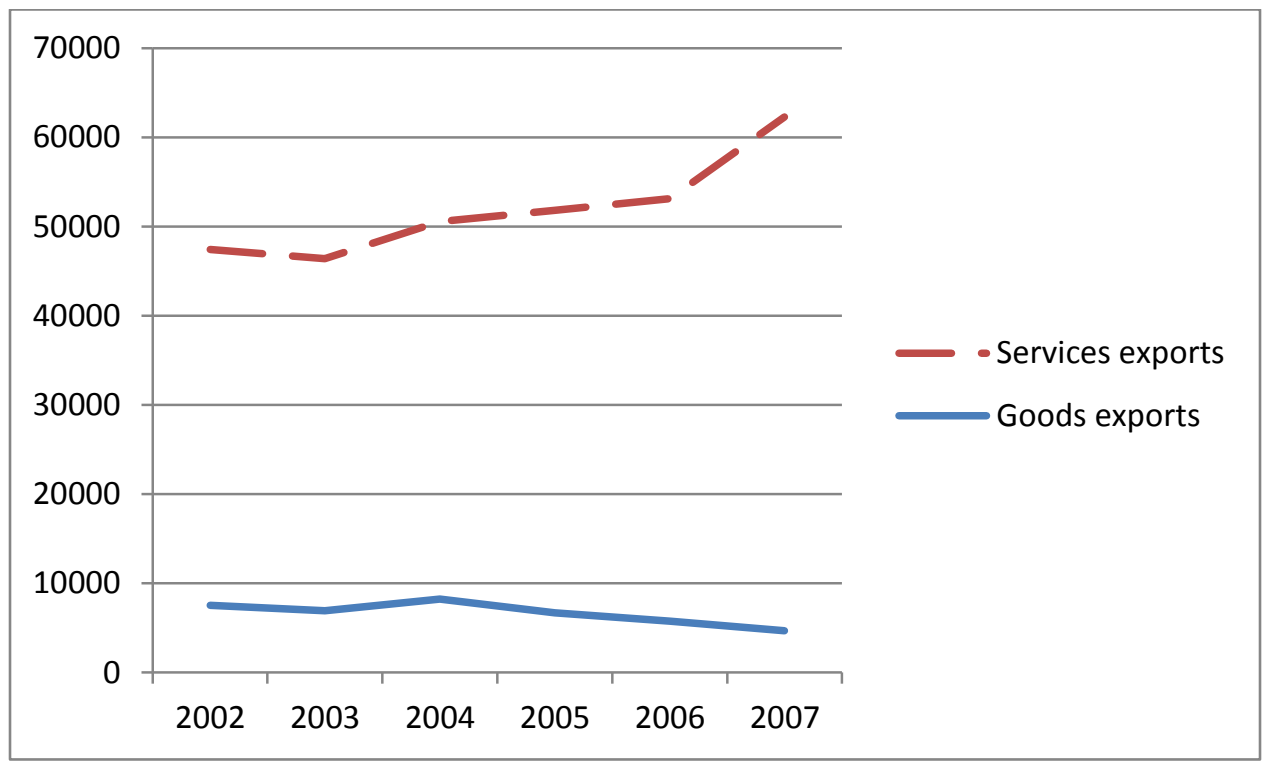

Source: NBB, Regional Accounts (2009) and OECD (OECD Statistics on International Trade in Services, 2008) 


\subsection{Industry sector}

The Regional Accounts of the National Bank of Belgium (NBB) provide information on Brussels exports to 145 trading partners. In order to focus our analysis, we restrict ourselves to the 20 most important partner countries. Table 1 lists the 20 most important countries that Brussels exports to according to their share in total Brussels exports for 2002 and 2008. Together they constitute about $90 \%$ of total Brussels exports.

Table 1: Value (in mio Euro) and share (share in total Brussels exports) of the goods exports of the Brussels Capital Region to the most important trading partners for 2002 and 2008.

\begin{tabular}{|l|r|r|l|r|r|}
\hline & \multicolumn{2}{|c|}{2002} & \multicolumn{2}{c|}{2008} \\
\hline & Value & Share & & Value & Share \\
\hline France & 1617 & 21.43 & France & 1222 & 22.09 \\
\hline Germany & 1379 & 18.28 & Germany & 1128 & 20.38 \\
\hline The Netherlands & 823 & 10.90 & The Netherlands & 698 & 12.61 \\
\hline United Kingdom & 631 & 8.37 & Italy & 434 & 7.85 \\
\hline Italy & 595 & 7.88 & Luxemburg & 266 & 4.80 \\
\hline Luxemburg & 488 & 6.46 & United Kingdom & 263 & 4.75 \\
\hline United States & 377 & 5.00 & Spain & 201 & 3.64 \\
\hline Spain & 347 & 4.60 & United States & 113 & 2.05 \\
\hline Switzerland & 117 & 1.55 & Switzerland & 99 & 1.79 \\
\hline Austria & 76 & 1.01 & Turkey & 76 & 1.37 \\
\hline Sweden & 73 & 0.96 & Austria & 73 & 1.32 \\
\hline Greece & 61 & 0.81 & Sweden & 73 & 1.31 \\
\hline Portugal & 49 & 0.65 & Poland & 70 & 1.27 \\
\hline Algeria & 45 & 0.59 & Denmark & 49 & 0.88 \\
\hline Turkey & 43 & 0.58 & Norway & 45 & 0.82 \\
\hline Denmark & 42 & 0.55 & Czech Republic & 31 & 0.75 \\
\hline Ireland & 39 & 0.52 & Jordan & 37 & 0.67 \\
\hline Russian Federation & 37 & 0.50 & Congo & 32 & 0.61 \\
\hline Poland & 30 & 0.40 & Russian Federation & 76 & 0.59 \\
\hline Japan & 29 & 0.38 & Portugal & & 0.54 \\
\hline
\end{tabular}

Source: NBB, Regional Accounts (2009) and own calculations

Table 1 illustrates the importance of Belgium's neighbouring countries for Brussels exports. France, Germany and the Netherlands together represent about $50 \%$ of total Brussels exports. The value of Brussels exports decreased in several markets, in particular in the United Kingdom, the United States, Luxemburg, Italy and Greece. These decreases are compensated for by higher exports to 'EUnewcomers' such as Poland (whose share tripled), Czech Republic (now in top 20) and Turkey (whose share doubled).

According to the Harmonized Commodity Description and Coding System (HS) of the World Customs Organization (WCO), the goods sector can be divided into 21 different sections that can be further split up into of 97 chapters. In order to get a better understanding of the goods exports, we focus on the 21 sections that roughly correspond to the main sectors of an economy. Our goal is to study the 
(evolution in the) main trading partners for the different sub-sectors. Table A1 in the Appendix summarizes the different sub-sectors and their share in total exports.

The four industrial sections with the largest value of exports are the transport equipment sector (section 17), the chemical sector (section 6), the leather sector (section 8) and the machinery sector (section 16). Their export shares were in 2008 respectively $22 \%, 15 \%, 15 \%$ and $13 \%$. Since they constitute more than half of total exports, we concentrate on these 4 sections. Tables $2-6$ summarize the 20 most important trading partners for each sub-sector.

Table 2: Value (in mio Euro) and share (share in total Brussels exports) of exports of goods from the Brussels Capital Region to the most important trading partners for 2002 and 2008 for the transport equipment sector

\begin{tabular}{|l|r|r|l|r|r|}
\hline & \multicolumn{2}{|c|}{2002} & & \multicolumn{2}{|c|}{2008} \\
\hline & Value & Share & & Value & Share \\
\hline Germany & 2763 & 27.71 & Italy & 1414 & 21.12 \\
\hline France & 766 & 17.95 & Germany & 299 & 20.07 \\
\hline United Kingdom & 496 & 13.66 & France & 284 & 19.36 \\
\hline Italy & 377 & 11.30 & United Kingdom & 274 & 6.78 \\
\hline The Netherlands & 312 & 9.51 & Spain & 96 & 4.80 \\
\hline Spain & 263 & 7.61 & The Netherlands & 68 & 4.05 \\
\hline Luxemburg & 210 & 2.55 & Luxemburg & 57 & 2.85 \\
\hline Austria & 70 & 1.50 & Austria & 40 & 2.54 \\
\hline Ireland & 41 & 1.01 & Jordan & 36 & 2.40 \\
\hline Switzerland & 28 & 0.96 & Norway & 34 & 1.99 \\
\hline Greece & 26 & 0.67 & Switzerland & 28 & 1.87 \\
\hline Denmark & 18 & 0.58 & United States & 26 & 1.49 \\
\hline Slovenia & 16 & 0.52 & Poland & 21 & 1.36 \\
\hline Croatia & 14 & 0.43 & Croatia & 19 & 0.85 \\
\hline Russian Federation & 12 & 0.39 & Angola & 12 & 0.78 \\
\hline Finland & 11 & 0.38 & Congo & 8 & 0.58 \\
\hline Congo & 11 & 0.25 & Czech Republic & 8 & 0.57 \\
\hline Dominican Republic & 7 & 0.22 & Slovenia & 8 & 0.54 \\
\hline Morocco & 6 & 0.20 & Denmark & 8 & 0.49 \\
\hline Angola & 6 & 0.19 & Benin & & \\
\hline
\end{tabular}

Source: NBB, Regional Accounts (2009) and own calculations

As far as the sector of transport goods is concerned (Table 2), we conclude that the share of the topfive trading partners has decreased over time: from 80 to 72 percent. Countries such as Austria, Switzerland and Congo became more important destination markets. Finally, countries such as Greece, Russia, Finland, Morocco and Dominican Republic disappear from the top 20. 
Table 3: Value (in mio Euro) and share (share in total Brussels exports) of exports of goods from the Brussels Capital Region to the most important trading partners for 2002 and 2008 for the chemical sector

\begin{tabular}{|l|r|r|l|r|r|}
\hline & \multicolumn{2}{|c|}{2002} & & \multicolumn{2}{|c|}{2008} \\
\hline & Value & Share & & Value & Share \\
\hline Germany & 267 & 24.66 & Germany & 331 & 34.08 \\
\hline United States & 231 & 21.32 & The Netherlands & 220 & 22.63 \\
\hline France & 162 & 14.99 & France & 163 & 16.78 \\
\hline The Netherlands & 80 & 7.38 & Luxemburg & 45 & 4.67 \\
\hline Luxemburg & 55 & 5.11 & United Kingdom & 35 & 3.58 \\
\hline United Kingdom & 46 & 4.21 & Sweden & 35 & 3.57 \\
\hline Sweden & 32 & 2.95 & Denmark & 28 & 2.86 \\
\hline Italy & 22 & 1.99 & Spain & 18 & 1.84 \\
\hline Spain & 19 & 1.72 & Italy & 17 & 1.73 \\
\hline Turkey & 15 & 1.39 & Czech Republic & 12 & 1.22 \\
\hline Portugal & 9 & 0.87 & Poland & 10 & 1.05 \\
\hline Taiwan & 9 & 0.83 & Switzerland & 6 & 0.62 \\
\hline Poland & 9 & 0.82 & Finland & 5 & 0.60 \\
\hline South-Africa & 8 & 0.74 & Romania & 4 & 0.50 \\
\hline Greece & 8 & 0.71 & Hungary & 4 & 0.45 \\
\hline Denmark & 5 & 0.49 & Congo & 3 & 0.34 \\
\hline Brazil & 5 & 0.42 & Russian Federation & 3 & 0.31 \\
\hline Austria & 4 & 0.40 & Austria & 2 & 0.24 \\
\hline Switzerland & 4 & 0.39 & Rwanda & 2 & 0.19 \\
\hline Czech Republic & 4 & 0.38 & Turkey & & 5 \\
\hline
\end{tabular}

Source: NBB, Regional Accounts (2009) and own calculations

As far as the chemical sector is concerned (Table 3), we observe an increase in the importance of the five main trading partners over time (from 73 to 81 percent). Even more surprisingly is the disappearance of the United States from the top-20. Contrary to the transport sector, exports in the chemical sector have thus been directed more and more to a limited number of markets. This of course automatically implies a smaller share for other markets that Brussels exports to. We can state in other words that the geographical diversification of the chemical sector decreases as opposed to the transport sector. This observation may at least partly be explained by the fact that Belgian chemical firms are mainly suppliers of intermediate goods to the chemical sector in neighbouring countries, especially in Germany. 
Table 4: Value (in mio Euro) and share (share in total Brussels exports) of exports of goods from the Brussels Capital Region to the most important trading partners for 2002 and 2008 for the leather sector

\begin{tabular}{|l|r|r|l|r|r|}
\hline & \multicolumn{2}{|c|}{2002} & & \multicolumn{2}{c|}{2008} \\
\hline & Value & Share & & 354.57 & 37.31 \\
\hline France & 250.85 & 36.40 & France & 104.35 & 10.98 \\
\hline Germany & 104.85 & 15.22 & Germany & 91.29 & 9.61 \\
\hline The Netherlands & 65.60 & 9.52 & United Kingdom & 72.54 & 7.63 \\
\hline United Kingdom & 55.61 & 8.07 & The Netherlands & 72.17 & 7.59 \\
\hline Italy & 47.57 & 6.90 & Spain & 48.70 & 5.13 \\
\hline Spain & 45.28 & 6.57 & Italy & 21.41 & 2.25 \\
\hline Sweden & 9.56 & 1.39 & Poland & 15.84 & 1.67 \\
\hline Austria & 9.44 & 1.37 & Turkey & 14.61 & 1.54 \\
\hline Denmark & 8.97 & 1.30 & Japan & 14.43 & 1.52 \\
\hline Switzerland & 8.92 & 1.29 & Czech Republic & 14.31 & 1.51 \\
\hline Portugal & 8.87 & 1.29 & Sweden & 12.77 & 1.34 \\
\hline Japan & 7.64 & 1.11 & Portugal & 11.64 & 1.23 \\
\hline Luxemburg & 7.42 & 1.08 & Austria & 11.25 & 1.18 \\
\hline Greece & 6.09 & 0.88 & Denmark & 10.68 & 1.12 \\
\hline Finland & 5.52 & 0.80 & Greece & 9.00 & 0.95 \\
\hline Poland & 4.01 & 0.58 & Luxemburg & 6.40 & 0.67 \\
\hline Norway & 3.95 & 0.57 & Finland & 5.64 & 0.59 \\
\hline Ireland & 3.76 & 0.55 & Switzerland & 4.88 & 0.51 \\
\hline United States & 3.73 & 0.54 & Hungary & 4.65 & 0.49 \\
\hline Russian Federation & 3.53 & 0.51 & Russian Federation & &
\end{tabular}

Source: NBB, Regional Accounts (2009) and own calculations

Traditionally, the leather sector is a successful Brussels export sector with increasing exports between 2002 and 2008. The decreasing importance of the second largest export market, namely Germany, is however remarkable. Given the fact that in value terms the export to Germany remained constant, its export value decreased from 15 to 11 percent. Several Central and Eastern-European countries became important export destinations, Poland in particular (increase from 0,58 to 2,25 percent almost a quadrupling of the exports), as well as Turkey and Hungary. The increased wealth in these countries after the economic transition period may explain the increased exports of luxury goods such as leather. We will dig deeper into this finding in Section 4. 
Table 5: Value (in mio Euro) and share (share in total Brussels exports) of exports of goods from the Brussels Capital Region to the most important trading partners for 2002 and 2008 for the machinery sector

\begin{tabular}{|l|r|r|l|r|r|}
\hline & \multicolumn{2}{|c|}{2002} & & \multicolumn{2}{|c|}{2008} \\
\hline & Value & Share & & Value & Share \\
\hline France & 218 & 23.06 & France & 848 & 25.16 \\
\hline The Netherlands & 138 & 14.65 & Germany & 213 & 14.88 \\
\hline Germany & 80 & 8.53 & The Netherlands & 126 & 11.02 \\
\hline United Kingdom & 71 & 7.51 & Luxemburg & 93 & 7.94 \\
\hline Luxemburg & 69 & 7.36 & Turkey & 67 & 7.64 \\
\hline Italy & 68 & 7.18 & Italy & 65 & 4.48 \\
\hline United States & 33 & 3.52 & Spain & 38 & 3.10 \\
\hline Spain & 33 & 3.51 & United Kingdom & 26 & 2.54 \\
\hline Algeria & 23 & 2.45 & Sweden & 22 & 2.54 \\
\hline Nigeria & 15 & 1.60 & Algeria & 22 & 2.31 \\
\hline Sweden & 14 & 1.51 & Congo & 20 & 1.47 \\
\hline Norway & 12 & 1.23 & Switzerland & 12 & 1.16 \\
\hline Switzerland & 11 & 1.20 & Denmark & 8 & 0.97 \\
\hline Denmark & 10 & 1.01 & Czech Republic & 8 & 0.92 \\
\hline Russian Federation & 9 & 0.92 & Poland & 7 & 0.83 \\
\hline Israel & 8 & 0.84 & Portugal & 7 & 0.78 \\
\hline Czech Republic & 7 & 0.78 & Austria & 7 & 0.66 \\
\hline Austria & 7 & 0.78 & Russian Federation & 6 & 0.63 \\
\hline Congo & 7 & 0.72 & United States & 5 & 0.59 \\
\hline Malaysia & 6 & 0.66 & Norway & & \\
\hline
\end{tabular}

Source: NBB, Regional Accounts (2009) and own calculations

As opposed to the leather sector, we observe in Table 5 an increasing share of Germany for the machinery sector (from 9 to 15 percent). This is at the expense of countries such as Italy and the United States. The share of other EU countries remains fairly stable.

We can conclude that, generally speaking, Belgium's neighbouring countries are Brussels' most important export destinations. As far as the transport sector is concerned, we observe a decrease in the importance of the top- 6 share which is creating new export opportunities to countries such as Austria and Switzerland. In the chemical sector exports, Germany, the Netherlands and France become ever more important. The machinery exports remain oriented mainly towards Germany while in the leather sector we observe an increasing importance of Central- and Eastern European countries such as Poland, Hungary and Turkey. 


\subsection{Services sector}

The importance of the services sector for Brussels exports became clear in the first paragraph. Detailed data regarding export destinations and subsectors are, however, not easily available for the services sector, especially not at regional level. Therefore we derive this information from a combination of data sources: we combine OECD trade data at the national level with NBB data of value added at the regional level. The OECD provides us with national data on sectoral and bilateral trade in services with different partners. We combine these data with data regarding value added of the NBB at the regional level. We thus transform the national data to regional data by multiplying them with the share of value added of the Brussels Capital Region in total Belgian value added.

We provide an overview of the most important export destinations for the services sector in 2002 and $2007^{2}$. Table 6 illustrates that the main trading partners are stable - as was the case for industry exports. The neighbouring countries, as well as the United States and Switzerland maintain the largest shares. Their common share decreases over time though from 78 to 63 percent. By contrast, trading partners such as Poland, Singapore, Greece, Hong Kong and Finland experience a doubling of their share.

Table 6: Value (in mio Euro) and share (share in total Brussels export) of exports of services of Brussels Capital Region to main export markets for 2002 and 2007

\begin{tabular}{|l|r|r|l|r|r|}
\hline & \multicolumn{2}{|c|}{2002} & & \multicolumn{2}{c|}{2007} \\
\hline & Value & Share & & Value & Share \\
\hline The Netherlands & 6318 & 15.85 & The Netherlands & 7994 & 12.72 \\
\hline United States & 6203 & 15.56 & France & 7509 & 11.95 \\
\hline United Kingdom & 5539 & 13.89 & United Kingdom & 6357 & 10.12 \\
\hline Germany & 4750 & 11.92 & United States & 5977 & 9.51 \\
\hline France & 4674 & 11.72 & Germany & 5921 & 9.42 \\
\hline Luxemburg & 2387 & 5.99 & Switzerland & 3389 & 5.39 \\
\hline Switzerland & 1388 & 3.48 & Luxemburg & 2326 & 3.70 \\
\hline Italy & 885 & 2.22 & Italy & 1730 & 2.75 \\
\hline Sweden & 668 & 1.68 & Japan & 1099 & 1.75 \\
\hline Spain & 657 & 1.65 & Spain & 1078 & 1.72 \\
\hline Japan & 640 & 1.61 & Ireland & 977 & 1.55 \\
\hline Ireland & 531 & 1.33 & Sweden & 910 & 1.45 \\
\hline Denmark & 295 & 0.74 & Finland & 886 & 1.41 \\
\hline Norway & 283 & 0.71 & Denmark & 729 & 1.16 \\
\hline Austria & 229 & 0.57 & China & 641 & 1.02 \\
\hline Finland & 219 & 0.55 & Poland & 557 & 0.89 \\
\hline Hong Kong & 175 & 0.44 & Hong Kong & 535 & 0.85 \\
\hline Greece & 105 & 0.26 & Singapore & 521 & 0.83 \\
\hline Singapore & 101 & 0.25 & Norway & 453 & 0.80 \\
\hline Poland & 6318 & 0.24 & Greece & 0.72 \\
\hline
\end{tabular}

Source: NBB, Regional Accounts (2009) and OECD (OECD Statistics on International Trade in Services, 2008)

${ }^{2}$ This was the most recent year for which services data were available. 
Services can also be divided in subsectors of which Table A2 in the Appendix gives an overview. In 2007 the top 4 of subsectors constituted $80 \%$ of total services exports. The subsectors 'Other commercial services' and 'Other business services' are the largest with shares of 21 and 36 percent respectively. The transport and travel sector have shares of 15 and 12 percent respectively. Given the rather vague definition of the first two sub-sectors and given the fact that data regarding the trading partners in these sub-sectors are incomplete, we focus our attention on the transport and travel sector. Tables 7 and 8 list the main export markets.

Table 7: Value (in mio Euro) and share (share in total Brussels export) of exports of transport services of Brussels Capital Region to main export markets for 2002 and 2007

\begin{tabular}{|l|r|r|l|r|r|}
\hline & \multicolumn{2}{|c|}{2002} & & \multicolumn{2}{|c|}{2007} \\
\hline Germany & Value & Share & & Value & Share \\
\hline United Kingdom & 302 & 17.48 & The Netherlands & 473 & 13.75 \\
\hline France & 245 & 14.18 & Germany & 466 & 13.57 \\
\hline United States & 243 & 14.07 & France & 460 & 13.40 \\
\hline The Netherlands & 241 & 13.92 & United Kingdom & 321 & 9.34 \\
\hline Luxemburg & 215 & 12.41 & Switzerland & 239 & 6.96 \\
\hline Switzerland & 80 & 4.63 & United States & 141 & 4.11 \\
\hline Sweden & 70 & 4.01 & Italy & 104 & 3.01 \\
\hline Italy & 47 & 2.66 & China & 88 & 2.57 \\
\hline Finland & 34 & 1.95 & Denmark & 86 & 2.51 \\
\hline Spain & 22 & 1.30 & Hong Kong & 79 & 2.29 \\
\hline Denmark & 21 & 1.22 & Sweden & 73 & 2.13 \\
\hline Japan & 18 & 1.02 & Luxemburg & 67 & 1.96 \\
\hline Norway & 17 & 0.98 & Singapore & 47 & 1.38 \\
\hline Middle East & 15 & 0.86 & Finland & 45 & 1.31 \\
\hline Austria & 14 & 0.82 & Japan & 42 & 1.22 \\
\hline Canada & 13 & 0.74 & Spain & 42 & 1.21 \\
\hline Ireland & 12 & 0.67 & Norway & 42 & 1.20 \\
\hline South Africa & 12 & 0.67 & South America & 40 & 1.17 \\
\hline Hong Kong & 12 & 0.67 & South Africa & 39 & 1.13 \\
\hline
\end{tabular}

Source: NBB, Regional Accounts (2009) and OECD (OECD Statistics on International Trade in Services, 2008)

Remarkable for the transport sector is the importance of EU member countries. Note however that the importance of export countries such as the United Kingdom and France decreases while the position of the Netherlands as export destination becomes more important. The share of the United States as an export market has decreased as well. A decrease in the share of the 'larger' players implies more opportunities for (new) 'smaller' players. Moreover, the exports of transport services are thus spreading out over more different trading partners. 
Table 8: Value (in mio Euro) and share (share in total Brussels export) of exports of travel services of Brussels Capital Region to main export markets for 2002 and 2007

\begin{tabular}{|l|r|r|l|r|r|}
\hline & \multicolumn{2}{|c|}{2002} & & \multicolumn{2}{|c|}{2007} \\
\hline & Value & Share & & Value & Share \\
\hline The Netherlands & 445 & 32.14 & The Netherlands & 391 & 25.95 \\
\hline France & 236 & 17.04 & France & 354 & 23.49 \\
\hline Germany & 172 & 12.49 & Germany & 131 & 8.69 \\
\hline United Kingdom & 158 & 11.40 & United Kingdom & 117 & 7.76 \\
\hline Luxemburg & 81 & 5.86 & Luxemburg & 109 & 7.27 \\
\hline Japan & 66 & 4.70 & United States & 44 & 2.92 \\
\hline United States & 44 & 3.24 & Italy & 29 & 1.93 \\
\hline Switzerland & 34 & 2.49 & Spain & 28 & 1.89 \\
\hline Spain & 27 & 1.95 & Switzerland & 14 & 0.91 \\
\hline Italy & 24 & 1.78 & Poland & 10 & 0.67 \\
\hline Sweden & 10 & 0.70 & Sweden & 9 & 0.59 \\
\hline Denmark & 7 & 0.52 & Japan & 9 & 0.58 \\
\hline Ireland & 6 & 0.45 & Portugal & 7 & 0.54 \\
\hline Poland & 5 & 0.40 & Denmark & 7 & 0.44 \\
\hline Austria & 5 & 0.40 & Russian Federation & 6 & 0.42 \\
\hline Portugal & 5 & 0.34 & Ireland & 6 & 0.39 \\
\hline Australia & 5 & 0.34 & Canada & 6 & 0.37 \\
\hline Finland & 4 & 0.30 & Greece & 5 & 0.35 \\
\hline Canada & 4 & 0.29 & Austria & 5 & 0.34 \\
\hline Norway & 4 & 0.29 & China & 79 & 9 \\
\hline
\end{tabular}

Source: NBB, Regional Accounts (2009) and OECD (OECD Statistics on International Trade in Services, 2008)

As far as the travel sector is concerned, it is mainly the changes in the top 4 that are remarkable. The share of neighbouring country France increases while the share of other neighbouring countries declines (the Netherlands, Germany and United Kingdom - joint decrease of 55 to 40 percent). Similar to the transport sector we observe a spreading of the export destinations increasing possibilities for 'new' trading partners. In 2007, China and Russia for instance also appear in the top 20.

The observed dynamics in Brussels exports in general, and the changes in the ranking of the different export markets for both goods and services raise questions regarding the future pattern of Brussels exports. In order to answer this question we first need to thoroughly understand the determinants of these exports. In section 3 we will study these determinants. Next, we can use the findings in order to make predictions regarding future evolutions of the trade flows, which will be done in section 4 . 
3. Determinants of Brussels exports

In order to pinpoint the determinants of Brussels exports, we estimate a gravity model. This model is the workhorse of the empirical trade literature. The intuition behind a gravity model is simple, i.e. large countries trade more while more distant trading partners trade less. The simple gravity model can be extended in order to include other trade determinants like the impact of regional trade agreements, common border effects etc. Extensive theoretical research has demonstrated the model's validity (see a.o. Deardorff (1995), Feenstra et al (2001) and Anderson and van Wincoop (2004)).

The gravity model explains the variation in bilateral export flows between two trading partners by changes in the GDP of the exporter or importer (growth effect), changes in the GDP per capita of the exporter and importer (income growth effect) as well as by the geographical distance between them. We take these determinants into account as well as some extra geographic or trade-related determinants that are commonly used in the literature. We will estimate gravity equation (1) in order to explain Brussels exports:

(1) $X_{B i t}=\beta_{0}+\beta_{1} G D P_{B t}+\beta_{2} G D P_{i t}+\beta_{3} G D P C A P_{B t}+\beta_{4} G D P C A P_{i t}+\beta_{5} D I S T_{B i}$ $+\beta_{6} B O R D E R_{B i}+\beta_{7} E U 15_{i}+\beta_{8} E U 27_{i}+\varepsilon_{i t}$

where

- $X_{B i t}$ denotes the exports from Brussels to country $i$ in year $t$

- $G D P_{B t}$ is the gross domestic product of Brussels in year $t$ (growth-effect exporter)

- $G D P_{i t}$ is the gross domestic product of export destination market in year $t$ (growth-effect importer)

- $G D P C A P_{B t}$ is the gross domestic product per capita of Brussels in year $t$ (income growtheffect exporter)

- $G D P C A P_{i t}$ is the gross domestic product per capita of export destination market in year $t$ (income growth-effect importer)

- $D I S T_{B i}$ is the great circle distance (in $\mathrm{km}$ ) between Brussels and country $i$ s capital city

- $B O R D E R_{B i}$ is a dummy equal to one if the destination market shares a border with Belgium, and equal to zero otherwise

- $E U 15_{i}$ is a dummy equal to one if the destination market belongs to the EU15, and equal to zero otherwise (effect of western European integration)

- $E U 27_{i}$ is a dummy equal to one if the destination market is one of the EU27 member states that joined in 2004 or 2007, and equal to zero otherwise (effect of Central and Eastern European integration)

- $\varepsilon_{i t}$ denotes an i.d.d. error term 
We expect a positive growth-effect of both Brussels and the partner country. Indeed, economic growth corresponds to a positive business cycle effect and leads to higher exports. Similarly, if an importing economy grows, its demand for foreign goods in absolute terms will increase and therefore its imports grow.

As far as the income growth-effect is concerned, we expect a positive impact from the income growth in Brussels. Richer countries are - generally speaking - able to produce more efficiently, produce more differentiated goods and services and/or more technologically advanced products. One may therefore a priori expect a richer country to export more. The impact of income growth in the importing country is, however, not straightforward. On the one hand, demand may be higher in a country with a higher income per capita. For instance, the demand for luxury goods will increase. On the other hand, a richer country may import fewer standard goods. Hence the effect on total trade depends on the exact composition of total trade flows.

For several reasons one may expect a negative impact of distance on bilateral trade. First of all, transportation costs depend on distance. Shipping goods over a longer distance increases costs and makes the trade relationship more costly and therefore more unlikely. Moreover, we know that countries that are further apart are less economically integrated. Therefore, distance additionally represents various transaction costs and barriers to trade. Apart from the distance effect, we also include a common border effect because, generally speaking, countries trade most with their neighbouring countries. This can be due to cultural or historical agreements or out of practical considerations.

Finally, we add two EU-dummies. They reflect the importance of the Single European Market boosting intra-European trade flows. One might indeed expect the abolishment of formal trade inhibitions (like tariffs, quota, export restrictions) and the minimal technical trade inhibitions (cfr. European health and safety regulations, European technical norms) to promote intra-European trade. We distinguish between the EU-15 and the EU-27 in order to distinguish explicitly between the old and the new EU member states. A positive effect for the old EU member states would imply a trade-creating effect thanks to longstanding integration between western European countries, whereas a positive effect for the new EU member states would point to a trade-creating effect as a result from the recent EU enlargement towards Central and Eastern European Countries.

Note that the common border dummy and the EU-dummies may interact with the distance effect. Brussels' European partners are often also its neighbouring countries and closest trading partners. We will have to consider the fact that both effects either co-exist or rather measure similar effects.

We estimate equation (1) for Brussels exports, distinguishing between goods and services. The estimation results for different versions of equation (1) for the goods sector in total are summarized in Table $9^{3}$. Table 10 illustrates the results for the services sector. In order to simplify the

\footnotetext{
${ }^{3}$ Note that in all estimations we drop GDP per capita of Brussels because it is too strongly correlated with the GDP of Brussels. We estimate a panel for 5 (services) or 6 years (goods) with time dummies using a random
} 
interpretation of our results, we take logarithms of all variables apart from the dummies. Finally, we also estimate the model for various industrial sectors. These results are reported in Table $3 \mathrm{~A}$ in the Appendix. All models are estimated using random effects GLS estimators ${ }^{4}$.

\section{Table 9: Estimation results for exports of goods}

\begin{tabular}{|l|c|c|c|}
\hline & $(1)$ & $(2)$ & $(3)$ \\
\hline GDP Brussels & $4.18^{* * *}$ & $1.34^{* * *}$ & $3.90^{* * *}$ \\
& $(0.32)$ & $(0.15)$ & $(0.35)$ \\
\hline GDP export market & $0.89^{* * *}$ & $0.87^{* * *}$ & $0.89^{* * *}$ \\
& $(0.06)$ & $(0.06)$ & $(0.06)$ \\
\hline GDP/capita export market & -0.18 & -0.09 & $-0.15^{*}$ \\
& $(0.08)$ & $(0.09)$ & $(0.08)$ \\
\hline Distance to Brussels & $-1.28^{* * *}$ & & $-1.13^{* * *}$ \\
& $(0.12)$ & & $(0.14)$ \\
\hline Dummy for neighbour & & $1.71^{* * *}$ & \\
\hline Dummy for EU15 & & $(0.83)$ & \\
& & $0.53^{* *}$ & $(0.67)$ \\
\hline Dummy for EU27 & & $1.87^{* * *}$ & $0.72^{*}$ \\
\hline $\mathrm{R}^{2}$ & 0.68 & $(0.46)$ & $(0.39)$ \\
\hline
\end{tabular}

Note: Standard errors in brackets; *, ** and ${ }^{* * *}$ respectively indicate significance at the $10 \%, 5 \%$ and $1 \%$ level

As far as the industry sector is concerned, we observe strong and significant growth effects from both Brussels and the export markets. This implies that Brussels will export more as it grows and that it will export more to larger or fast-growing markets. The geographic and trade-related determinants have an important impact too. The distance to the trading partner has a strong negative impact on Brussels exports. We can dig deeper into this effect by studying column (2) in Table 9. Brussels indeed trades a lot with Belgium's neighbouring countries. Note also that it has a stronger export position towards the EU-27 compared to the EU-15. Column (3) finally allows us to conclude that the European integration effect is more than a mere reduced distance between the EU partners. Even for a given distance, the fact that the trading partner is a member of the EU has a positive impact on Brussels exports.

effects GLS estimation. We do however simultaneously control for GDP and GDP per capita of the destination market. By doing so, we follow the tradition of the gravity literature, although the interpretation of the coefficients becomes less straightforward: a higher coefficient for GDP per capita implies a positive effect of a higher average income (either because of an income increase over time or because of a higher average income compared to other destination markets), keeping the destination market's GDP constant. Since we take logarithms, it actually measures the impact of a population decrease.

${ }^{4}$ The random effects estimator is preferred since using a fixed effects estimator would drop out several crucial gravity variables (e.g., distance). Moreover the Hausman specification test argues in favour of the random effects estimator. 
Next, we analyse the estimation results for the different industrial subsectors. The results can be found in Table A3 in the Appendix. These findings largely confirm our results for total industrial exports. Apart from the results for the weapon industry (Section 19), they have a meaningful interpretation. The results show that for the different industrial sub-sectors there is almost always a positive growth-effect from both Brussels and the export markets. Sectoral differences are mainly caused by sector-specific characteristics. The income-growth effect of the importer is mostly insignificant. As we argued before, the impact of GDP per capita of the importing country is indeed not clear-cut. For some luxury products, we obtain a positive impact as expected. Countries with richer consumers can indeed spend more on luxury products. For instance, for the leather sector, we indeed note such a positive income-growth effect. This could be due to the fact that sectors with luxury goods mainly aim at markets with a larger income growth. We reached the same conclusion in our first section where we established the fact that the leather export to countries such as Poland, Turkey and Hungary experienced a substantial increase. Brussels leather and art (e.g. antique) have a strong international reputation which may explain these positive effects.

Distance to the export market plays an important role for every sector although there are small differences across the different sectors. There are large neighbour- and EU-effects, although the differences between the different sectors are substantial. For instance, we observe a large neighboureffect for the sectors of living animals and minerals - typically sectors with large transport costs. The EU-27 effect is particularly strong for the leather- and art sector, again indicating the importance of new member states for these sectors. Finally note that we did not find evidence for a specific EU-15 effect, analogous to the total industry findings ${ }^{5}$. The integration of new EU member states in 2004 and 2007, however, has been very successful from a Brussels export point of view. For Brussels exporters, the EU-27 as one large, integrated market is an important stimulus.

The results for the Brussels services exports are similar to the results for the Brussels goods exports. Note that we are unable to make a distinction between the different service-subsectors. Table 10 summarizes the results.

\footnotetext{
${ }^{5}$ Results of these estimation available with the authors upon request.
} 
Table 10: Estimation results for exports of services

\begin{tabular}{|l|c|c|c|}
\hline & $(1)$ & $(2)$ & $(3)$ \\
\hline GDP Brussels & 20.71 & 24.80 & 22.7 \\
& $(24.34)$ & $(24.50)$ & $(23.71)$ \\
\hline GDP export market & $0.64^{* * *}$ & $0.62^{* * *}$ & $0.61^{* * *}$ \\
& $(0.03)$ & $(0.03)$ & $(0.03)$ \\
\hline GDP/capita export market & $0.31^{* * *}$ & $0.24^{* * *}$ & $0.27^{* * *}$ \\
& $(0.04)$ & $(0.04)$ & $(0.04)$ \\
\hline Distance to Brussels & $-0.67^{* * *}$ & & $-0.35^{* * *}$ \\
& $(0.06)$ & & $(0.07)$ \\
\hline Dummy for neighbour & & $1.91^{* * *}$ & $1.46^{* * *}$ \\
& & $(0.29)$ & $(0.33)$ \\
\hline Dummy for EU15 & & $0.84^{* * *}$ & $0.56^{* *}$ \\
& & $(0.25)$ & $(0.25)$ \\
\hline Dummy for EU27 & & $0.59^{* * *}$ & $0.40^{* *}$ \\
& & $(0.18)$ & $(0.19)$ \\
\hline $\mathrm{R}^{2}$ & 0.76 & 0.78 & 0.78 \\
\hline
\end{tabular}

Note: Standard errors in brackets; *,** and ${ }^{* * *}$ respectively indicate significance at the $10 \%$, $5 \%$ and $1 \%$ level

First of all, we note that economic growth in Brussels does not have a direct impact on export of services. This implies that the evolution in Brussels services export is mainly the result of international factors and developments. Secondly, it is mainly the growth as well as the incomegrowth in the trading partners that stimulate Brussels services exports. The growth-effect in each estimation outweighs the income-growth effect. Also, for the services sector, we find a negative impact of distance. Note however that the effect is smaller for services than for goods. This makes sense given the fact that service exports often do not imply physical transactions but rather happen over e.g. the internet (like consulting, financial services). Finally, we note that Brussels exports remain mainly oriented towards the neighbouring countries and EU trading partners - mainly the EU-15. As far as services are concerned, the Brussels exports remain mainly oriented towards the closest trading partners. There is, however, still a distinction between the 'old' and 'new' EU member states. Brussels exports are more directed to the old than to the new EU member states.

\section{Future of Brussels exports}

We use the gravity equation from Section 3 with all determinants to make extrapolations for the future. Our prognoses make it possible to list the most important export markets for Brussels and the export markets for which there is still a large growth potential.

In order to make these predictions we use the gravity model from Table 9, column 3 for the goods trade and the gravity model from Table 10, column 3 for the trade in services. We look at data for 2014 since this is the last year for which the IMF makes predictions. We use data projections by the IMF for GDP and GDP-capita for the exporter markets in 2014. One should not consider this as exact data only for that particular year but rather as an indication of middle-long-term prognoses. We 
assume the GDP of Brussels not to change between 2008 and $2014^{6}$ and we consider no changes in EU membership.

Since reporting all our predictions would be rather uninformative, we restrict ourselves to the relative ranking of the different trading partners based on the future Brussels export potential towards these markets. Again we focus on both the goods and services sector.

\subsection{Predictions regarding future prospective of Brussels goods exports}

Table 11 provides an overview of Brussels trading partners classified according to their future export growth potential for Brussels exporters. We have 5 categories:

- Countries with "Very little export growth potential"

- Countries with "Little export growth potential"

- Countries with a "Status Quo" position

- Countries with an "Export growth potential"

- Countries with a "Large export growth potential"

Trading partners with very little or little growth potential are countries for which we expect Brussels exports not to increase strongly. This does not exclude, however, that exports in absolute terms may increase over the following years, but the increase will at best be limited to a 'normal' evolution. One moreover cannot exclude decreases in exports. There are two possible reasons why trading partners may belong to either one of these two categories. One the one hand, it may be markets to which Brussels exports are currently strong, in that way leaving little room for further increases. The export relationship is mature and currently in line with the expected possibilities. On the other hand, these categories may contain markets that are hardly important to Brussels, e.g. because of their limited market size or large distance to Brussels. The group of countries in this category is thus very diverse. Some very important trading partners are part of this group, like Germany, Italy, Luxemburg, the United States, Switzerland and Turkey. This indicates that the future prospects for the export of goods are not bright. A decreasing importance of the largest export markets is to be expected and will only reinforce the general decline in goods exports.

The "Status Quo" category contains countries to which Brussels companies future exports will remain fairly stable. Remarkable again are the large number of EU-countries in this category. Although the predictions for large trading partners such as France and the Netherlands are somewhat more positive, it is unlikely that they can compensate for the possible decrease in exports towards the countries in the previous two categories.

Finally, there are countries where the Brussels exports are expected to increase. The number of countries belonging to the categories with "Growth potential" and "Large growth potential" is high. In other words, Brussels exporters have a large choice of (new) countries to export to. Nevertheless,

${ }^{6}$ This is of course unrealistic but we neglect this impact because we know it will be positive. Moreover, by doing so, our prognoses are more conservative. 
it seems appropriate to focus on a limited number of trading partners. First of all, we note that many Latin-American countries belong to these categories (e.g. Peru, Brazil, Mexico, Costa Rica, Venezuela, Chile, ...). Secondly, there are many Asian countries in the list like e.g. China, India, Pakistan, the Philippines and Vietnam.

Generally speaking, one can say that the countries with the highest economic-growth potential are the most important candidates for exporting Brussels products to. Finally, we note the position of the UK. Although it has always been one of Brussels' main trading partners, our findings indicate that the British are expected to buy even more Brussels goods in the future. 
Table 11: Classification of exporting markets based on their prediction for goods exports

\begin{tabular}{|c|c|c|c|c|}
\hline Very little export growth potential & Little export growth potential & Status Quo & Export growth potential & Large export growth potential \\
\hline Burundi & Qatar & The Netherlands & Uruguay & Ethiopia \\
\hline Congo & Comoros & Saudi-Arabia & Iran & Paraguay \\
\hline Guinea & Croatia & Slovenia & Romania & United Kingdom \\
\hline Rwanda & Iceland & Finland & Russian Federation & Libya \\
\hline Jordan & Italy & Macedonia & Armenia & Pakistan \\
\hline Benin & Germany & Zambia & Bulgaria & Vietnam \\
\hline Cameroon & Norway & Thailand & Serbia & Tadzhikistan \\
\hline Seychelles & Lithuania & France & Sri Lanka & Uzbekistan \\
\hline Togo & Ghana & Egypt & Albania & China \\
\hline Equatorial-guinea & Tanzania & Colombia & Botswana & Namibia \\
\hline Gabon & Israel & Estonia & Peru & Philippines \\
\hline Canada & Uganda & Denmark & Lebanon & Zimbabwe \\
\hline Guinea-Bissau & Sierra Leone & Georgia & Bosnia-Herzegovina & Kenya \\
\hline Belize & Morocco & Czech Republic & Malta & Costa Rica \\
\hline Madagascar & Portugal & Mali & Brazil & Mozambique \\
\hline Senegal & Switzerland & & Jamaica & Bhutan \\
\hline IvoryCoast & Sweden & & Hungary & Chile \\
\hline Angola & Moldavia & & Guyana & Nicaragua \\
\hline Cyprus & South Korea & & Nigeria & El Salvador \\
\hline Hong Kong & Taiwan & & DominicanRepublic & Trinidad and Tobago \\
\hline Ukraine & Yemen & & Kuwait & Eritrea \\
\hline Gambia & Kyrgyzstan & & Cape Verde & Fiji \\
\hline Luxemburg & United States & & Mexico & Lesotho \\
\hline Sao Tomé en Principe & Japan & & Panama & Sudan \\
\hline Djibouti & New Zealand & & Barbados & Honduras \\
\hline Lithuania & Austria & & Suriname & Iraq \\
\hline Turkey & Malaysia & & Azerbaijan & Malawi \\
\hline Maldives & Australia & & Indonesia & Mongolia \\
\hline UAE & Central-African Republic & & Kazakhstan & Bangladesh \\
\hline Bahrain & Greece & & Laos & Bolivia \\
\hline Mauritania & South-Africa & & Belarus & Afghanistan \\
\hline Mauritius & Burkina Faso & & Argentina & Nepal \\
\hline Singapore & Niger & & Venezuela & Haiti \\
\hline Tunisia & Poland & & Chad & Papua New Guinea \\
\hline Algeria & Liberia & & Guatemala & Brunei Darussalam \\
\hline Syria & & & India & Bahamas \\
\hline Ecuador & & & Slovakia & Myanmar \\
\hline Oman & & & & Swaziland \\
\hline
\end{tabular}


4.2. Predictions regarding future prospective of Brussels service exports

The prognoses concerning the future of trade in Brussels services are much more positive and unambiguous than the prognoses for the Brussels goods trade. Apart from Liberia, Burundi and Switzerland we find a positive export potential growth for all trading partners. This indicates that the future of Brussels exports is mainly in service activities.

Table 12 ranks the trading partners according to their export growth potential. Given the largely positive results as far as services export potential is concerned, we distinguish between three categories:

- Countries with "Little export growth potential"

- Countries with an "Export growth potential"

- Countries with a "Large export growth potential"

Hence we exclude the categories of countries with "Very little export growth potential" and the countries with a "Status quo position" that we discussed in our analysis for the industry sector.

The first group of countries exhibits little export growth potential in the service sector - i.e. it entails the countries with a negative or very small growth potential. In this list we find mainly African countries, but also some important European export markets such as Germany and the Netherlands. This category indeed includes both markets that are currently hardly of any importance to Brussels as well as markets to which Brussels exports are currently very strong.

The second category consists of countries with an intermediate export potential. In this category we encounter a large number of Central- and Eastern European countries, whether or not EU members. Examples are Turkey, Poland, Hungary, Bulgaria, Slovenia and the Czech Republic. Hence not only does the actual EU enlargement play a role here, but services exports to candidate EU member states are also likely to increase.

Finally, the category of countries with a large export potential includes few Western-European countries, but many Latin-American countries. The limited presence of Western-European countries is of course due to the strong focus Brussels currently has on the European Union markets, and particularly on the neighbouring countries. Only France, and to a lesser degree Austria, are still potential growth markets for Brussels services exports. The strong position of Latin-American countries indicates that this continent is interesting for both goods and service exports in the future. By contrast, a different conclusion holds for Asian countries and for the US. They have a large potential for future Brussels goods exports, but less so for Brussels services exports. 
Table 12: Classification of exporting markets based on their prediction for services exports

\begin{tabular}{|c|c|c|}
\hline Little export growth potential & Export growth potential & Large export growth potential \\
\hline Liberia & Turkey & Moldova \\
\hline Burundi & Panama & Chile \\
\hline Switzerland & Japan & Chad \\
\hline Singapore & Finland & Russian Federation \\
\hline Ghana & Gabon & Bahrain \\
\hline Hong Kong, China & Poland & Guyana \\
\hline Bahamas & India & Austria \\
\hline Luxembourg & Ireland & Viet Nam \\
\hline South Africa & Mozambique & Niger \\
\hline United States & New Zealand & Romania \\
\hline Mauritius & Hungary & Angola \\
\hline Netherlands & Norway & Armenia \\
\hline Malta & Central AfricanRepublic & Lithuania \\
\hline Rwanda & Kenya & Iran \\
\hline Côted'Ivoire & Tunisia & Seychelles \\
\hline Portugal & Tanzania & Belize \\
\hline Congo & Pakistan & Ethiopia \\
\hline Madagascar & Uganda & Syrian Arab Republic \\
\hline Djibouti & China & Burkina Faso \\
\hline Cyprus & Georgia & Fiji \\
\hline Togo & Jordan & Slovak Republic \\
\hline Guinea & Ukraine & Macedonia \\
\hline Nigeria & Senegal & Antigua and Barbuda \\
\hline Sierra Leone & Zambia & Croatia \\
\hline Malawi & United ArabEmirates & Albania \\
\hline Cameroon & Morocco & Sudan \\
\hline Germany & Sweden & Qatar \\
\hline Zimbabwe & Lebanon & Nicaragua \\
\hline Samoa & Bulgaria & Nepal \\
\hline \multirow[t]{24}{*}{ United Kingdom } & Egypt & France \\
\hline & Thailand & Cape Verde \\
\hline & Iceland & Papua New Guinea \\
\hline & Namibia & Lao People's Democratic Republic \\
\hline & Benin & Kyrgyzstan \\
\hline & Korea & Estonia \\
\hline & Italy & Dominican Republic \\
\hline & Gambia & Bosnia and Herzegovina \\
\hline & Greece & Oman \\
\hline & Sri Lanka & Mexico \\
\hline & LibyanArabJamahiriya & Tajikistan \\
\hline & Israel & Colombia \\
\hline & Denmark & Ecuador \\
\hline & Malaysia & Costa Rica \\
\hline & Philippines & Venezuela \\
\hline & Mali & Cambodia \\
\hline & Barbados & Uzbekistan \\
\hline & Mauritania & Azerbaijan \\
\hline & Slovenia & Suriname \\
\hline & Spain & Yemen \\
\hline & Argentina & Paraguay \\
\hline & Australia & Afghanistan \\
\hline & Brazil & Trinidad and Tobago \\
\hline & Bangladesh & Peru \\
\hline
\end{tabular}




\begin{tabular}{|l|l|l|}
\hline & Canada & Honduras \\
& Sao Tomeand Principe & Bolivia \\
& Latvia & Kuwait \\
& Uruguay & Botswana \\
& Democratic Republic of the Congo & Kazakhstan \\
& Algeria & El Salvador \\
& Indonesia & Guatemala \\
& CzechRepublic & Brunei Darussalam \\
& SaudiArabia & Jamaica \\
& Swaziland & Belarus \\
\hline
\end{tabular}

\section{Conclusion}

This paper studies the extent of geographical reorientation and diversification in Brussels exports. In particular, it adds new evidence based on city-level exports to the literature on dynamic trade effects caused by the recent European Union enlargement.

We find that the European Union member states remain the most important destination markets for Brussels' companies. The new European Union member states are gradually becoming more important destination markets, in particular for several luxury goods sectors like leather and arts. For services, the new European Union member states are becoming more important trading partners.

Based on a gravity model, we analyzed the main determinants of Brussels exports. Again we made a distinction between the goods and services sector. The analysis shows that goods and services exports are largely determined by similar factors. Economic growth and income growth in the export markets clearly have a positive impact on the exports. Moreover, exports decrease if the distance between Brussels and its trading partners - and therefore transport costs or trade barriers - increases. The findings also confirm that Brussels mainly focuses on neighbouring countries and European Union member states. The negative impact of distance is smaller for services exports than for goods exports. The opposite is true for the EU-integration effect. Remarkable is also the positive impact of growth in Brussels on goods exports while Brussels growth does not influence services exports. The latter are therefore mainly determined by international developments. As far as various industrial sectors are concerned, we note that it is mainly the exports in the luxury sectors like leather and art that are driven by higher incomes in the export markets.

Based on our gravity estimation results, we finally make predictions regarding the future of Brussels exports. Generally speaking, we obtain evidence for various challenges in the goods sector and positive evolutions in the services sector. Our predictions point to an even further negative trend in Brussels goods exports. The government could try to stop this evolution by supporting Brussels firms both in current exporting markets as well as in exploring new export markets. As far as the goods exports are concerned, we find evidence for substantial growth possibilities in Latin-America and Asia, but also in particular new European Union member states. Contrary to the goods sector, the prospects for the services sector are much better. There are growth opportunities in almost all markets. The most opportunities are to be found in a 
number of specific European countries such as France and Austria, as well as in a large number of Central- and Eastern European countries and mainly in Latin-America.

Globalisation - and more in particular the EU enlargement - has obviously both a positive and a negative impact on Brussels exports. On the one hand, there is a very strong competition in the goods sector (in particular, those sub-sectors where Brussels has a comparative disadvantage compared to other countries, such as in labour intensive sectors). On the other hand, there are more and more options for the services sector. Services will be ever more traded internationally and (partly) compensate for the loss in competitiveness in the goods sector. Moreover, we expect Brussels to remain important in some goods sectors where it does have a comparative advantage such as in capital intensive sectors of luxury goods like leather and arts. 


\section{References}

Abraham, F., Konings, J., Veugelers, R., Van Hove, J., Vansteenkiste, I. (2002), De Nieuwe EU: Doodsteek voor de Vlaamse Economie? (The New EU: Deathblow for the Flemish Economy?), Acco Publisher, Leuven, 118p.

Anderson, J.E. and van Wincoop, E. (2004), Trade Costs, Journal of Economic Literature, 42 (3), pp. 691-751.

Baldwin, R., Francois, J., and Portes (1997), EU Enlargement: Small Costs for the West, Big Gains for the East, Economic Journal, 24, pp. 127-176.

Bussiere, M., Fidrmuc, J., Schnatz, B. (2008) EU Enlargement and Trade Integration: Lessons from a Gravity Model, Review of Development Economics, 12(3), pp. 562-576.

Deardorff, A.V. (1995), Determinants of Bilateral Trade: Does Gravity work in a Neoclassical World?, NBER working paper 5377.

Djankov, S, Hoekman, B. (1998), Trade Reorientation and Post-Reform Productivity Growth in Bulgarian Enterprise, Journal of Policy Reform, 2(2), pp.151-168.

Feenstra, R.C., Markusen, J.A., and Rose, A.K. (2001), Using the Gravity Equation to Differentiate among Alternative Theories of Trade, Canadian Journal of Economics, 34 (2), pp. 430-442.

Hoekman, B., Djankov, S. (1999), Intra-Industry Trade, Foreign Direct Investment, and Reorientation of Eastern European Exports, The World Bank, Policy Research Working paper Series, 1652.

Kandogan, Y. (2006), The Reorientation of Transition Countries' Exports: Changes in Quantity, Quality and Variety, Review of European Economic Policy, 41(4), pp. 216-229.

Lejour, A., De Mooij, R.A., and NahuisR. (2001), EU Enlargement: Economic Implications for Countries and Industries, CESifo Working paper Series, $\mathrm{n}^{\circ} 585$.

May, J.B. (2009), Trade and Migration in an Enlarged European Union: A Spatial Analysis, Global Economy Journal, 9(4).

Nahuis, R. (2004), One Size Fits All? Accession to the Internal Market; an Industry Level Assessment of EU Enlargement, Journal of Policy Modeling, 26 (5), pp. 571-586.

Papazoglou, Ch., Pentecost, E.J. , Marquez, H. (2006) A Gravity Model Forecast of the Potential trade Effects of EU Enlargement: Lessons from 2004 and Path-Dependency in Integration, World Economy, 29(8), pp. 1077-1089. 
Shepotylo, O. (2010), A Gravity Model of Net Benefits of EU Membership: The Case of Ukraine, Journal of economic Integration, 25(4), pp. 676-702.

Winiecki, J. (2000), Successes of Trade Orientation and Expansion in post-Communist Transition: An Enterprise-Level Approach, Banca Nazionale del Lavoro Quartely Review, 53(213), pp. 187-223. 


\section{Appendix}

Table A1: Sections within the industrial sector according to the HS of the WCO

\begin{tabular}{|l|l|c|}
\hline & & Share \\
\hline Section 1 & Live animals; animal products & 1.06 \\
\hline Section 2 & Crops products & 2.31 \\
\hline Section 3 & Animal fats & 0.05 \\
\hline Section 4 & Prepared food; drinks; tobacco & 4.03 \\
\hline Section 5 & Minerals & 3.16 \\
\hline Section 6 & Chemical goods & 15.16 \\
\hline Section 7 & Plastic and rubber & 2.03 \\
\hline Section 8 & Leather & 14.82 \\
\hline Section 9 & Wood & 0.37 \\
\hline Section 10 & Paper & 2.91 \\
\hline Section 11 & Textiles & 4.76 \\
\hline Section 12 & Footwear & 0.21 \\
\hline Section 13 & Stone; cement; ceramic; glass & 0.43 \\
\hline Section 14 & Precious metals; jewelry & 2.48 \\
\hline Section 15 & Metals & 4.81 \\
\hline Section 16 & Machinery & 13.23 \\
\hline Section 17 & Transport equipment & 22.04 \\
\hline Section 18 & Optics; photography; watches; music instruments; medical instruments & 3.35 \\
\hline Section 19 & Weapons and ammunition & 1.32 \\
\hline Section 20 & Others & 1.32 \\
\hline Section 21 & Art & 0.16 \\
\hline
\end{tabular}

Source: World Customs Union

Table A2: Share of the different services sub-sectors

\begin{tabular}{|l|l|c|}
\hline & & Share \\
\hline Sector 1 & Communication & 2.95 \\
\hline Sector 2 & Computer and information & 3.06 \\
\hline Sector 3 & Construction & 2.25 \\
\hline Sector 4 & Financial sector & 3.80 \\
\hline Sector 5 & Government & 2.63 \\
\hline Sector 6 & Insurances & 0.86 \\
\hline Sector 7 & Other business services & 21.05 \\
\hline Sector 8 & Other commercial services & 35.59 \\
\hline Sector 9 & Personal. cultural and recreational services & 0.49 \\
\hline Sector 10 & Royalties and licenses & 1.12 \\
\hline Sector 11 & Transport & 14.83 \\
\hline Sector 12 & Travel & 11.86 \\
\hline
\end{tabular}

Source: OECD (OECD Statistics on International Trade in Services, 2008) 
Table A3a: Estimation results for exports of goods in various industrial sectors

\begin{tabular}{|c|c|c|c|c|c|c|}
\hline & $\begin{array}{l}\text { GDP } \\
\text { Brussels }\end{array}$ & $\begin{array}{l}\text { GDP export } \\
\text { market }\end{array}$ & $\begin{array}{l}\text { GDP/capita export } \\
\text { market }\end{array}$ & $\begin{array}{l}\text { Distance to } \\
\text { Brussels }\end{array}$ & $\begin{array}{l}\text { Dummy for } \\
\text { neighbour }\end{array}$ & $\begin{array}{l}\text { Dummy for } \\
\text { EU27 }\end{array}$ \\
\hline \multirow{2}{*}{$\begin{array}{l}\text { Section } 1 \\
\text { Live animals; animalproducts }\end{array}$} & $\begin{array}{c}2.83 * * * \\
(0.60) \\
\end{array}$ & $\begin{array}{c}0.39 * * * \\
(0.11) \\
\end{array}$ & $\begin{array}{r}-0.22 \\
(0.16) \\
\end{array}$ & $\begin{array}{c}-0.73 * * * \\
(0.21) \\
\end{array}$ & & \\
\hline & $\begin{array}{c}1.26 * * * \\
(0.23)\end{array}$ & $\begin{array}{c}0.27 * * * \\
(0.10)\end{array}$ & $\begin{array}{l}-0.17 \\
(0.14)\end{array}$ & & $\begin{array}{c}4.59 * * * \\
(0.76) \\
\end{array}$ & $\begin{array}{c}0.53 \\
(0.45) \\
\end{array}$ \\
\hline \multirow{2}{*}{$\begin{array}{l}\text { Section } 2 \\
\text { Crops products }\end{array}$} & $\begin{array}{c}3.31 * * * \\
(0.54)\end{array}$ & $\begin{array}{c}0.54 * * * \\
(0.11)\end{array}$ & $\begin{array}{l}-0.02 \\
(0.14)\end{array}$ & $\begin{array}{c}-1.46^{* * *} \\
(0.19)\end{array}$ & & \\
\hline & $\begin{array}{c}0.11 \\
(0.22) \\
\end{array}$ & $\begin{array}{c}0.41 * * * \\
(0.11)\end{array}$ & $\begin{array}{c}0.05 \\
(0.13) \\
\end{array}$ & & $\begin{array}{c}3.74 * * * \\
(0.76) \\
\end{array}$ & $\begin{array}{c}2.22 * * * \\
(0.44) \\
\end{array}$ \\
\hline \multirow{2}{*}{$\begin{array}{l}\text { Section } 3 \\
\text { Animal fats }\end{array}$} & $\begin{array}{c}2.52^{* * *} \\
(0.87)\end{array}$ & $\begin{array}{c}0.42 * * * \\
(0.16) \\
\end{array}$ & $\begin{array}{c}-0.43^{* *} \\
(0.23)\end{array}$ & $\begin{array}{c}-0.79 * * * \\
(0.29) \\
\end{array}$ & & \\
\hline & $\begin{array}{c}0.63^{* *} \\
(0.30) \\
\end{array}$ & $\begin{array}{l}0.25^{*} \\
(0.13) \\
\end{array}$ & $\begin{array}{l}-0.22 \\
(0.19) \\
\end{array}$ & & $\begin{array}{c}3.20 * * * \\
(0.66)\end{array}$ & $\begin{array}{c}0.01 \\
(0.57) \\
\end{array}$ \\
\hline \multirow{2}{*}{$\begin{array}{l}\text { Section } 4 \\
\text { Prepared food; drinks; tobacco }\end{array}$} & $\begin{array}{c}1.69 * * * \\
(0.44)\end{array}$ & $\begin{array}{c}0.68^{* * *} \\
(0.08)\end{array}$ & $\begin{array}{c}0.12 \\
(0.11) \\
\end{array}$ & $\begin{array}{c}-0.66^{* * *} \\
(0.16) \\
\end{array}$ & & \\
\hline & $\begin{array}{l}0.28^{*} \\
(0.17)\end{array}$ & $\begin{array}{c}0.62 * * * \\
(0.08)\end{array}$ & $\begin{array}{c}0.13 \\
(0.10) \\
\end{array}$ & & $\begin{array}{c}3.39 * * * \\
(0.76)\end{array}$ & $\begin{array}{c}0.81 * * \\
(0.40)\end{array}$ \\
\hline \multirow{2}{*}{$\begin{array}{l}\text { Section } 5 \\
\text { Minerals }\end{array}$} & $\begin{array}{c}2.77 * * * \\
(0.42)\end{array}$ & $\begin{array}{c}0.37 * * * \\
(0.08)\end{array}$ & $\begin{array}{l}-0.004 \\
(0.11)\end{array}$ & $\begin{array}{c}-0.99 * * * \\
(0.15)\end{array}$ & & \\
\hline & $\begin{array}{c}0.56 * * * \\
(0.17)\end{array}$ & $\begin{array}{c}0.26 * * * \\
(0.07)\end{array}$ & $\begin{array}{c}0.01 \\
(0.10)\end{array}$ & & $\begin{array}{c}5.80 * * * \\
(0.62)\end{array}$ & $\begin{array}{c}0.07 \\
(0.34)\end{array}$ \\
\hline \multirow{2}{*}{$\begin{array}{l}\text { Section } 6 \\
\text { Chemicals }\end{array}$} & $\begin{array}{c}2.98^{* * *} \\
(0.37)\end{array}$ & $\begin{array}{c}0.74 * * * \\
(0.07)\end{array}$ & $\begin{array}{l}-0.02 \\
(0.09)\end{array}$ & $\begin{array}{c}-0.95^{* * *} \\
(0.14) \\
\end{array}$ & & \\
\hline & $\begin{array}{c}0.94 * * * \\
(0.15)\end{array}$ & $\begin{array}{c}0.70 * * * \\
(0.07)\end{array}$ & $\begin{array}{l}-0.03 \\
(0.09) \\
\end{array}$ & & $\begin{array}{c}3.05^{* * *} \\
(0.69)\end{array}$ & $\begin{array}{c}1.67 * * * \\
(0.35)\end{array}$ \\
\hline \multirow{2}{*}{$\begin{array}{l}\text { Section } 7 \\
\text { Plastic and rubber }\end{array}$} & $\begin{array}{c}2.97 * * * \\
(0.34)\end{array}$ & $\begin{array}{c}0.77 * * * \\
(0.06)\end{array}$ & $\begin{array}{l}-0.13 \\
(0.09) \\
\end{array}$ & $\begin{array}{c}-1.04 * * * \\
(0.12)\end{array}$ & & \\
\hline & $\begin{array}{c}0.71 * * * \\
(0.15) \\
\end{array}$ & $\begin{array}{c}0.71 * * * \\
(0.07)\end{array}$ & $\begin{array}{c}-0.11 * * * \\
(0.09)\end{array}$ & & $\begin{array}{c}2.61 \\
(0.62) \\
\end{array}$ & $\begin{array}{c}1.78^{* * * *} \\
(0.32) \\
\end{array}$ \\
\hline
\end{tabular}


Table A3b: Estimation results for exports of goods in various industrial sectors

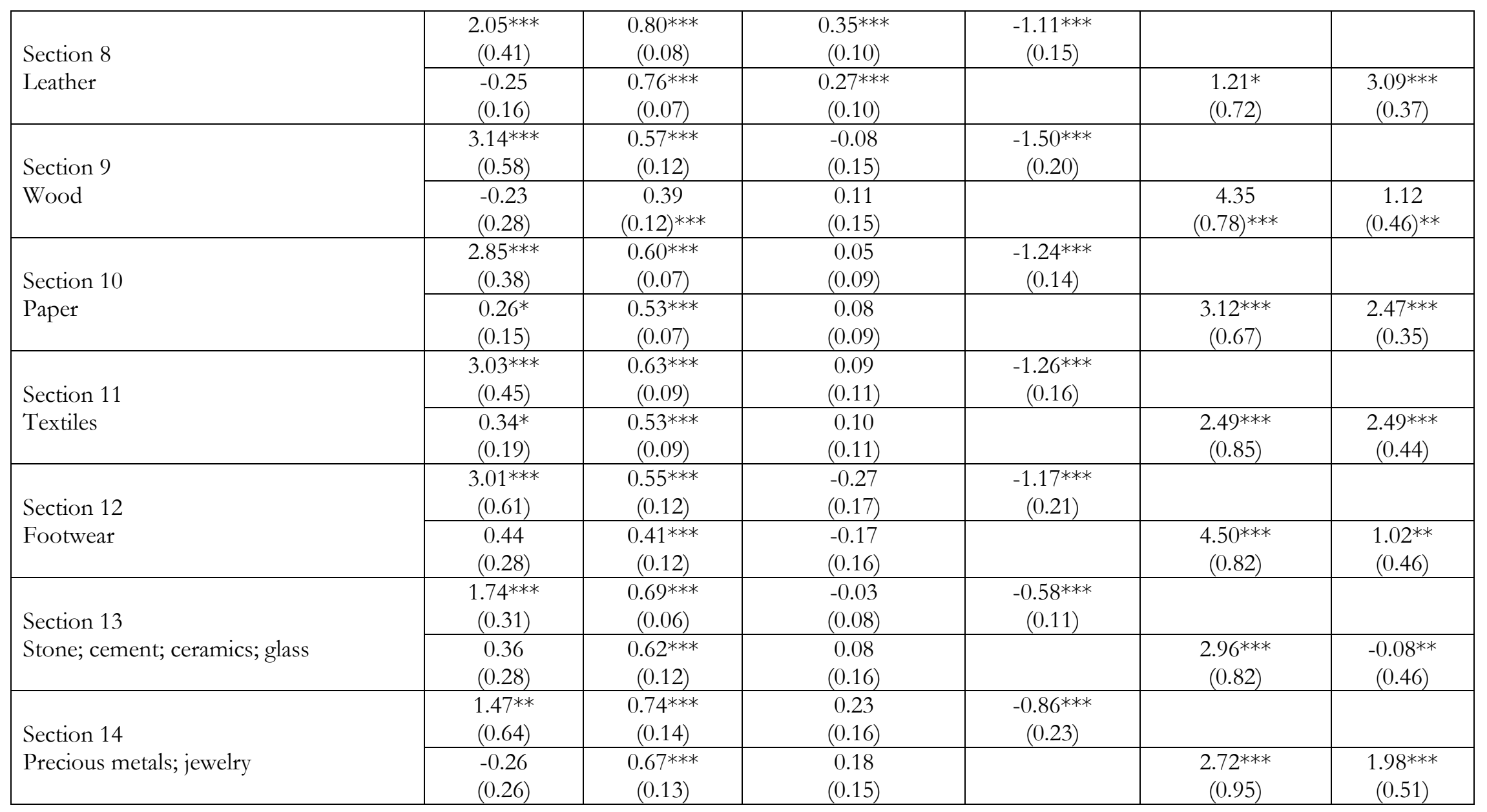


Table A3c: Estimation results for exports of goods in various industrial sectors

\begin{tabular}{|c|c|c|c|c|c|c|}
\hline \multirow{2}{*}{$\begin{array}{l}\text { Section } 15 \\
\text { Metals }\end{array}$} & $\begin{array}{c}2.50 * * * \\
(0.44)\end{array}$ & $\begin{array}{c}0.72 * * * \\
(0.08)\end{array}$ & $\begin{array}{c}0.01 \\
(0.11)\end{array}$ & $\begin{array}{c}-0.93 * * * \\
(0.16)\end{array}$ & & \\
\hline & $\begin{array}{c}0.41^{* *} \\
(0.18)\end{array}$ & $\begin{array}{c}0.67 * * * \\
(0.09)\end{array}$ & $\begin{array}{c}0.07 \\
(0.11)\end{array}$ & & $\begin{array}{c}2.72 * * * \\
(0.83)\end{array}$ & $\begin{array}{l}1.10^{* *} \\
(0.43) \\
\end{array}$ \\
\hline \multirow{2}{*}{$\begin{array}{l}\text { Section } 16 \\
\text { Machinery }\end{array}$} & $\begin{array}{c}3.44 * * * \\
(0.37)\end{array}$ & $\begin{array}{c}0.80 * * * \\
(0.07) \\
\end{array}$ & $\begin{array}{l}-0.10 \\
(0.09)\end{array}$ & $\begin{array}{c}-1.16^{* * *} \\
(0.14)\end{array}$ & & \\
\hline & $\begin{array}{c}0.89^{* * *} \\
(0.16)\end{array}$ & $\begin{array}{c}0.77 * * * \\
(0.07)\end{array}$ & $\begin{array}{l}-0.09 \\
(0.10) \\
\end{array}$ & & $\begin{array}{c}2.18^{* * *} \\
(0.88)\end{array}$ & $\begin{array}{c}2.20^{* * *} \\
(0.40) \\
\end{array}$ \\
\hline \multirow{2}{*}{$\begin{array}{l}\text { Section } 17 \\
\text { Transport means }\end{array}$} & $\begin{array}{c}5.21 * * * \\
(0.45)\end{array}$ & $\begin{array}{c}0.50 * * * \\
(0.08)\end{array}$ & $\begin{array}{l}-0.18 \\
(0.11) \\
\end{array}$ & $\begin{array}{c}-1.86 * * * \\
(0.16)\end{array}$ & & \\
\hline & $\begin{array}{c}1.10^{* * *} \\
(0.20)\end{array}$ & $\begin{array}{c}0.42^{* * *} \\
(0.09)\end{array}$ & $\begin{array}{l}-0.12 \\
(0.12) \\
\end{array}$ & & $\begin{array}{c}3.38 * * * \\
(0.99)\end{array}$ & $\begin{array}{c}3.15^{* * *} \\
(0.50) \\
\end{array}$ \\
\hline \multirow{2}{*}{$\begin{array}{l}\text { Section } 18 \\
\text { Optics; photography; watches; music } \\
\text { and medical instruments }\end{array}$} & $\begin{array}{c}2.44^{* * *} \\
(0.37)\end{array}$ & $\begin{array}{c}0.79 * * * \\
(0.07) \\
\end{array}$ & $\begin{array}{l}-0.09 \\
(0.09) \\
\end{array}$ & $\begin{array}{c}-0.94 * * * \\
(0.14) \\
\end{array}$ & & \\
\hline & $\begin{array}{c}0.44 * * * \\
(0.15)\end{array}$ & $\begin{array}{c}0.72 * * * \\
(0.07)\end{array}$ & $\begin{array}{l}-0.02 \\
(0.09)\end{array}$ & & $\begin{array}{c}2.15^{* * *} \\
(0.67)\end{array}$ & $\begin{array}{c}2.01 * * * \\
(0.35) \\
\end{array}$ \\
\hline \multirow{2}{*}{$\begin{array}{l}\text { Section } 19 \\
\text { Weapons and ammunition }\end{array}$} & $\begin{array}{l}-3.90^{*} \\
(2.17) \\
\end{array}$ & $\begin{array}{l}-0.13 \\
(0.29) \\
\end{array}$ & $\begin{array}{c}0.87 \\
(0.64) \\
\end{array}$ & $\begin{array}{c}1.63^{* *} \\
(0.61) \\
\end{array}$ & & \\
\hline & $\begin{array}{c}0.78 \\
(1.19) \\
\end{array}$ & $\begin{array}{c}0.19 \\
(0.27) \\
\end{array}$ & $\begin{array}{l}-0.12 \\
(0.61) \\
\end{array}$ & & $\begin{array}{c}-3.48^{* *} \\
(1.18) \\
\end{array}$ & $\begin{array}{r}2.02 \\
(1.44) \\
\end{array}$ \\
\hline \multirow{2}{*}{$\begin{array}{l}\text { Section } 20 \\
\text { Others }\end{array}$} & $\begin{array}{c}2.65^{* * *} \\
(0.39) \\
\end{array}$ & $\begin{array}{c}0.42 * * * \\
(0.08) \\
\end{array}$ & $\begin{array}{c}0.11 \\
(0.10) \\
\end{array}$ & $\begin{array}{c}-1.12 * * * \\
(0.14) \\
\end{array}$ & & \\
\hline & $\begin{array}{l}0.28^{*} \\
(0.15)\end{array}$ & $\begin{array}{c}0.35^{* * *} \\
(0.07) \\
\end{array}$ & $\begin{array}{c}0.10 \\
(0.10)\end{array}$ & & $\begin{array}{c}2.56 * * * \\
(0.66) \\
\end{array}$ & $\begin{array}{c}2.30 * * * \\
(0.34) \\
\end{array}$ \\
\hline \multirow{2}{*}{$\begin{array}{l}\text { Section } 21 \\
\text { Art }\end{array}$} & $\begin{array}{l}-0.56 \\
(0.64)\end{array}$ & $\begin{array}{l}0.50^{*} \\
(0.15)\end{array}$ & $\begin{array}{c}0.13 \\
(0.18) \\
\end{array}$ & $\begin{array}{c}0.23 \\
(0.21) \\
\end{array}$ & & \\
\hline & $\begin{array}{l}-0.23 \\
(0.30)\end{array}$ & $\begin{array}{c}0.46^{* * *} \\
(0.12)\end{array}$ & $\begin{array}{c}0.30 * * \\
(0.15)\end{array}$ & & $\begin{array}{l}1.75^{* *} \\
(0.74) \\
\end{array}$ & $\begin{array}{c}2.87^{* * *} \\
(0.51) \\
\end{array}$ \\
\hline
\end{tabular}

Note: Standard errors in brackets; *, ** and *** respectively indicate significance at the $10 \%, 5 \%$ and $1 \%$ level 